\title{
Correction to: Prediction of mortality in severely injured patients with facial bone fractures
}

\author{
levgen Shumynskyi ${ }^{1} \cdot$ Vitaliy Gurianov $^{2} \cdot$ Oleksandr Kaniura $^{3} \cdot$ Andrey Kopchak $^{1}$
}

Published online: 11 August 2021

○) Springer-Verlag GmbH Germany, part of Springer Nature 2021

\section{Correction to: Oral and Maxillofacial Surgery (2021)}

https://doi.org/10.1007/s10006-021-00967-7

The above article was published online with inverted given and family names. The correct presentation has been corrected above. The original article has been corrected.

Publisher's Note Springer Nature remains neutral with regard to jurisdictional claims in published maps and institutional affiliations.

The original article can be found online at https://doi.org/10.1007/ s10006-021-00967-7.

Ievgen Shumynskyi

shuminsky@icloud.com

1 Department of Dentistry, Institute of Postgraduate

Education, O. Bogomolets National Medical University, 34,

Peremohy Avenue, the 2nd floor of the "physical-chemical"

building, Kyiv, Ukraine

2 Health Management Department, O. Bogomolets National Medical University, 13, T. Shevchenko Blvd., Kyiv 01601, Ukraine

3 Department of Orthodontics and Prosthetic Dentistry,

O. Bogomolets National Medical University, 13,

T. Shevchenko Blvd., Kyiv 01601, Ukraine 